\title{
Influence of manganese fertilizer on efficiency of grapes on sandy soils of the Chechen Republic
}

\author{
A.A. Batukaev ${ }^{1}$, A.S. Magomadov ${ }^{1}$, and G.P. Malyh ${ }^{2}$ \\ ${ }^{1}$ The Chechen State University, Grozny, 364907, Sheripova str., 32, Russia \\ ${ }^{2}$ All-Russian Research Institute of Viticulture and Winemaking, Novocherkassk, Russia
}

\begin{abstract}
As a result of the studies, there has been obtained new information about the manganese influence on productivity of grape plantations, on sandy soils of the Chechen Republic. Manganese fertilizing of $4 \mathrm{~kg}$ active ingredient per $1 \mathrm{ha}$, against the background of nitrogen $90 \mathrm{~kg}$, phosphorus $90 \mathrm{~kg}$ and potassium $90 \mathrm{~kg} / \mathrm{ha}$, made it into a phase of grape sap flow, which contributes to higher yields, increase of the sugar content of the berries and a significant decrease in juice acidity, in comparison with other options.
\end{abstract}

\section{Introduction}

Grape is not only the most beautiful but also the most nutritious, delicious and the healthiest product. Viticulture cannot be conducted without taking into account the ecological potential of the region, soil and climatic conditions, the level of productive forces and production relations, technological advances, the requirements of nature protection, ensuring economic effect.

There has been recently began producing of vineyards bookmarks on the sands, both abroad and in our country, and many questions of mineral nutrition have to be developed for each region. It has been required to take a study of agrochemical properties of different types of sandy soils, content of macro- and micronutrients and their impact on the grape harvest.

Grape plants have a need in manganese throughout the growing period. Manganese enters the grapes plant in the form of ions $\mathrm{Mn}^{2+}$, the average manganese content according to our data in the shoots of grapes on sandy soils is $9-11 \mathrm{mg} / \mathrm{kg}$ of dry solids. Manganese is in varying degrees of oxidation $\left(\mathrm{Mn}^{2+}, \mathrm{Mn}^{3+}, \mathrm{Mn}^{4+}\right)$.

The role of manganese in the metabolism of plants is similar with magnesium and iron functions. It activates numerous ferments, especially under phosphorylation.

With the ability to transfer electrons by changing the valence, it participates in various redox reactions, being a part of redox ferments involved in the processes of respiration, photosynthesis, and carbohydrate and nitrogen metabolism of plants.

Manganese is involved in photosynthesis and vitamin $\mathrm{C}$ synthesis. Manganese is involved in water photolysis and is necessary for maintaining the structure of chloroplasts; it activates ferments involved in the oxidation of one of the plant hormones - indole acetic acid (IAA), which is essential for the hormonal regulation of growth [6].

The average manganese removal with the harvest is $1200-1500 \mathrm{~g} / \mathrm{ha}$. Since manganese activates ferments in the plant, its deficiency affects many metabolic processes, in particular for the synthesis of carbohydrates and proteins.

Signs of manganese deficiency in plants are mostly observed in carbonate, in strongly limed and some peaty and sandy soils at $\mathrm{pH}$ above 6.5. Manganese deficiency in plants is exacerbated at low temperature and high humidity [5].

Manganese deficiency becomes noticeable firstly on young leaves by a lighter green color or discoloration (chlorosis). Also, very soon appear brown necrotic spots. Besides leaves die faster than at iron deficiency [3-7]. The known sign of manganese lack is brown spotting, especially in demanding to manganese by Euro-Amur grape hybrids $[4,5]$.

Results of patent searches and synthesis of published data show that studies of the influence on the yield and quality of grapes and level of security manganese plants in sandy soils were conducted. Such studies are not only of great practical but also of the theoretical value.

Purpose of study was to examine the content of manganese in soils of Tersky sands and to identify the physiological of Platovsky grapes reaction to manganese fertilizer and to determine the effect of root feeding time and doses to productivity of vineyards.

\section{Methods and materials research}

Studies were carried out on fruiting vines Terek-Kumskiy sands of Schelkovskoy district vine producing farm "Burun" in the Chechen Republic. Agro biological counts - the number of buds, shoots, buds on the bushes, accounting harvest berries from the bush and 1 hectare, and the average mass of clusters were performed according to the method published in "agronomically intensive research on establishing the vineyards on industrial scale" [7].

Soil and plant samples were collected simultaneously for the determination of nitrogen, phosphorus, potassium,

This is an Open Access article distributed under the terms of the Creative Commons Attribution License 4.0, which permits unrestricted use, distribution, and reproduction in any medium, provided the original work is properly cited. 
Table 1. Batteries content at different depths of sandy soil state farm Burunny of Shelkovskoy District in the Chechen Republic, 2012.

\begin{tabular}{|c|c|c|c|c|c|c|c|c|c|c|}
\hline \multirow[t]{2}{*}{ Selection depth, $\mathrm{cm}$} & \multirow[t]{2}{*}{$\mathrm{pH}$} & \multirow[t]{2}{*}{ Humus, \% } & \multicolumn{2}{|c|}{\begin{tabular}{l|l} 
nutrients, $\mathrm{mg} / \mathrm{kg}$ of dry soil \\
Phosphorus & Potassium
\end{tabular}} & \multicolumn{6}{|c|}{ Content of microelements, $\mathrm{mg} / \mathrm{kg}$} \\
\hline & & & $\begin{array}{c}\text { Phosphorus } \\
\mathrm{P}_{2} \mathrm{O}_{5}\end{array}$ & $\begin{array}{c}\text { Potassium } \\
\mathrm{K}_{2} \mathrm{O}\end{array}$ & $\begin{array}{c}\text { Zinc } \\
\text { Zn }\end{array}$ & $\begin{array}{c}\text { Copper } \\
\mathrm{Cu}\end{array}$ & $\begin{array}{c}\text { Марганец } \\
\text { Mn }\end{array}$ & $\begin{array}{c}\text { Cobalt } \\
\text { Co }\end{array}$ & & $\begin{array}{c}\text { Boron } \\
\text { B }\end{array}$ \\
\hline \multicolumn{11}{|c|}{ Soil Analysis on 15.06 .2012} \\
\hline $0-20$ & 8,8 & $0, .67$ & 14,3 & 143 & 0,78 & 1,9 & 16,8 & & 0.53 & 0,4 \\
\hline $20-40$ & 8,8 & 0,66 & 10,0 & 121 & 0,73 & 1,3 & 14,4 & 0 & & 0,5 \\
\hline $40-60$ & 8,8 & 0,67 & 12,0 & 143 & 0,69 & 0.83 & 24,3 & & 0.12 & 0,4 \\
\hline $60-150$ & 8,8 & 0,95 & 13,0 & 132 & 0,51 & 0,26 & 8,5 & & 0.12 & 0,75 \\
\hline
\end{tabular}

calcium, magnesium and boron microelements, cobalt, manganese, molybdenum, zinc on atomic absorption spectrophotometer "Quantum - AFA GKNZH.01.00.OOO” on methodic of "Nuclear absorption method for determination of toxic elements" GOST (state standard) - 30178-96. R. Selection of soil - GOST (state standard) - 2816889; general requirements for conducting analyzes - GOST (State standard) - 29269-91; nitrate nitrogen in the soil GOST (state standard) - 26951-86; exchange ammonium in the soil - GOST (state standard) - 26489-85; mobile forms of phosphorus and potassium in the soil by the Machigin exchange method - GOST (state standard) 26205-91;

Growth and development of active roots were determined on V.A. Kolesnikov method (1960). Phenological observations, the study of aging degree of shoots, winter hardiness and productivity of the plants were carried out on M.A. Lazarevsky method (1963).

Sugar content of the berries was determined according to GOST (state standard) 27198-87, titratable acidity according to GOST (state standard) R51621-2000 (78) [1.2]. Statistical reliability of the results, according to Dospehova BA method (1971).

\section{Experience on different doses effect and timing of manganese fertilizer on growth, development and productivity of plantations is put by the following scheme:}

1. Option: Control (without micronutrients $\mathrm{N}_{90} \mathrm{R}_{90} \mathrm{~K}_{90}$ Background).

2. Option: background + Manganese $(2 \mathrm{~kg} / \mathrm{ha})$.

3. Option: background + Manganese ( $4 \mathrm{~kg} / \mathrm{ha})$.

4. Option: background + Manganese (6 kg / ha).

5. Option: background + Manganese $(8 \mathrm{~kg} / \mathrm{ha})$.

Fertilizers - sulphate manganese, ammonium silitra, super phosphate, potassium salt was put on into the soil just or into the phase of sap flow, or into the flowering stage, or into the phase growth and the beginning of the ripening berries by the hydro drills at the distance of $80 \mathrm{~cm}$ from the bush, to a depth of $30 \mathrm{~cm}$ per year. There were totally 16 wells in performed by hydro drills in each experimental variant. Grape planting of Platovsky grape variety (1998) are laid upon to $3 \times 1.0 \mathrm{~m}$ scheme. Variants of experience were laid in four replicates in each - four plants. Forming is long sleeved, vineyards are unsheltered.

\section{Results of research}

Studied sandy soils contain a small amount of humus. In the $0-20 \mathrm{~cm}$ soil layer its amount $-0.67 \%$ at a depth of $20-40 \mathrm{~cm}-0.66 \%$, and at a depth of $60-150 \mathrm{~cm}-0.95 \%$. $\mathrm{pH}$ ranges from 8.5 to 8.8. Phosphorus content in the 0 $20 \mathrm{~cm}$ horizon is $14.3 \mathrm{mg} / \mathrm{kg}$, at the depth of $20-40 \mathrm{~cm}$ $-10 \mathrm{mg} / \mathrm{kg}$, at $60-150 \mathrm{~cm}-13 \mathrm{mg} / \mathrm{kg}$ of dry substance. Amount of potassium on horizons: from 121 to $143 \mathrm{mg} / \mathrm{kg}$.

Total carbonate content is $2.1-2.3 \%$. Nitrogen in the sandy loam soil is observed only in total analysis and in a very small amount $0,020-0,040 \%$. Average content of total manganese in soils grapes employed in the test area is from 8.5 to $24.3 \mathrm{mg} / \mathrm{kg}$. The content of water-soluble manganese in studied soils on the average is $5.70 \mathrm{mg} / \mathrm{kg}$ or about $1.2 \%$ of the total amount.

The share of strongly bound compounds accounts for the major part of the total manganese content in the soil - more than $90 \%$. These include manganese in the primary and secondary minerals of silicate (clay minerals), and non-silicate (oxides, manganese hydroxides, salts) nature.

Manganese, tightly bound in the organic wastes and in its transformation products (including humic substances), has less effect on the overall level of manganese in the soil due to the relatively low share and significantly lower stability compared to mineral manganese carriers.

It should be noted that weather conditions were varied during the research that allowed examining their effects on vine plants. Average monthly spring and summer temperatures of 2011 were higher than historical averages (from $1,0{ }^{\circ} \mathrm{C}$ in April to $4,2^{\circ} \mathrm{C}$ in July). The summer was hot and the maximum temperature recorded at 28 July was $+39,6^{\circ} \mathrm{C}$. Maximum soil surface temperature on that day was $50^{\circ} \mathrm{C}$. In summer months, the air temperature was above perennial indicators $\left(1.8,4.2\right.$ and $1,6{ }^{\circ} \mathrm{C}$, respectively). The sum of active air temperatures during these months exceeded the long-term data on the $237.7^{\circ} \mathrm{C}$. Winter in 2011-2012 was snow less, with frequent thaws.

Snow cover is low and quite unstable. In the northern part of the country (Shelkovskoy district) had increased wind activity. For a year of research in 2011 was 30 days with strong winds. Their maximum speed reached $15 \mathrm{~m} / \mathrm{s}$. The annual rainfall was $341.4 \mathrm{~mm}$.

The coldest month in 2012 was January, the air temperature dropped to minus $35,7^{\circ} \mathrm{C}$ and February - to minus $34,8^{\circ} \mathrm{C}$. Shift through the average decade temperature plus $10^{\circ} \mathrm{C}$ was in early April.

Multiple slices on vines wood showed the presence of frost damages on bushes heads, sleeves and grapevines. 
Table 2. Time and dose effect of manganese fertilizer insertion on growth, development and productivity of grapes Platovsky plants (2011).

\begin{tabular}{|c|c|c|c|c|c|c|}
\hline Options of experience & $\begin{array}{c}\text { The average length } \\
\text { of shoots, }\end{array}$ & $\begin{array}{l}\text { The average diameter } \\
\text { of the shoots, mm }\end{array}$ & Yield, t/ha & $\begin{array}{l}\text { Sugar content of } \\
\text { the berries, } \mathrm{g} / \mathrm{dm}^{3}\end{array}$ & \multicolumn{2}{|l|}{$\begin{array}{c}\text { Increase to control } \\
\mathrm{t} / \mathrm{ha} \mathrm{g} / \mathrm{dm}^{3}\end{array}$} \\
\hline \multicolumn{7}{|c|}{ Insertion into the phase of sap flow } \\
\hline $\begin{array}{l}\text { I. Control (without micronutrients } \\
\mathrm{N}_{90} \mathrm{P}_{90} \mathrm{~K}_{90} \text { background) }\end{array}$ & 154,6 & 5,6 & 69,9 & 174 & - & - \\
\hline II. Background + Mn-2 kg/ha & 172,4 & 5,8 & 71,6 & 176 & 1,7 & 2 \\
\hline III. Background + Mn-4 kg/ha & 180,0 & 6,0 & 74,6 & 195 & 4,7 & 9 \\
\hline IV. Background + Mn-6 kg/ha & 171,4 & 5,9 & 73,3 & 183 & 6 & 5 \\
\hline V. Background + Mn-8 kg/ha & 160,5 & 5,9 & 70,5 & 176 & 0,6 & 2 \\
\hline $\mathrm{LSD}_{05}$ & & & 1,553 & & & \\
\hline \multicolumn{7}{|c|}{ Insertion into the flowering phase } \\
\hline $\begin{array}{l}\text { I. Control (without micronutrients } \\
\mathrm{N}_{90} \mathrm{P}_{9} \mathrm{OK}_{90} \text { background) }\end{array}$ & 153,9 & 5,4 & 69,8 & 170 & - & - \\
\hline II. Background + Mn-2 kg/ha & 160,3 & 5,5 & 71,0 & 174,3 & 1,2 & 4,3 \\
\hline III. Background+ Mn-4 kg/ha & 164,4 & 5,7 & 73,0 & 176,8 & 3,2 & 6,8 \\
\hline IV. Background+ Mn-6 kg/ha & 161,5 & 5,6 & 72,3 & 175,5 & 2,3 & 3,5 \\
\hline V. Background+ Mn-8 kg/ha & 161,0 & 5,5 & 70,0 & 173,8 & 0,2 & 3,8 \\
\hline $\mathrm{LSD}_{05}$ & & & 1,223 & & & \\
\hline \multicolumn{7}{|c|}{ Insertion into the phase of growth and beginning of berries ripening } \\
\hline $\begin{array}{l}\text { I. Control (without micronutrients } \\
\mathrm{N}_{90} \mathrm{P}_{9} \mathrm{OK}_{90} \text { background) }\end{array}$ & 140,0 & 5,1 & 69,7 & 170,0 & - & - \\
\hline II.Background + Mn-2 kg/ha & 141,6 & 5,1 & 70,1 & 171,0 & 0,4 & 1 \\
\hline III. Background + Mn-4 kg/ha & 149,4 & 5,2 & 71,6 & 173,5 & 0,9 & 3,5 \\
\hline IV. Background + Mn-6 kg/ha & 140,6 & 5,1 & 71,0 & 172,0 & 0,3 & 0,2 \\
\hline V. Background + Mn-8 kg/ha & 139,4 & 5,0 & 71,0 & 172,0 & 0,3 & 0,2 \\
\hline $\mathrm{LSD}_{05}$ & & & 1,226 & & & \\
\hline
\end{tabular}

Table 3. Influence of manganese fertilizer on root development of Platovsky grades in phase of sap flow (2011).

\begin{tabular}{|l|c|c|c|c|}
\hline \multirow{2}{*}{ Options of experience } & \multicolumn{2}{|c|}{ Air-dry weight of roots } & \multicolumn{2}{c|}{ Number of skeletal roots } \\
\cline { 2 - 5 } & & $\%$ to control & pieces & $\%$ to control \\
\hline $\begin{array}{l}\text { I. Control without micronutrients } \\
\mathrm{N}_{90} \mathrm{P}_{90} \mathrm{~K}_{90} \text { background }\end{array}$ & 385 & - & 400 & - \\
\hline II. Background + Mn-2 kg/ha & 398 & 103 & 422 & 106 \\
\hline III. Background + Mn-4 kg/ha & 426 & 110 & 462 & 116 \\
\hline IV. Background + Mn-6 kg/ha & 419 & 108 & 451 & 113 \\
\hline V. Background + Mn-8 kg/ha & 416 & 108 & 453 & 113 \\
\hline
\end{tabular}

Temperature at a depth of $30 \mathrm{~cm}$ of soil in the state farm "Burunny" briefly dropped to minus $10-14{ }^{\circ} \mathrm{C}$. As a result, the root system of the hybrids with the Amur grapes has been damaged on this depth.

Live roots was preserved, starting at the depth of $35 \mathrm{~cm}$ As showed our studies, manganese fertilizer had a positive effect on plant growth. So in 2011 on fertilization in the phase of sap flow the average length of shoots on the control without fertilizer was $154.6 \mathrm{~cm}$ in the version with the insertion of manganese into the phase of sap flow at the dose of $4 \mathrm{~kg} / \mathrm{ha}-180 \mathrm{~cm}$. It has been considerably reduced the growth on insertion of manganese into the flowering phase, respectively, $164.4 \mathrm{~cm}$, and even less growth was in the growth phase and in the beginning of berries ripening $-149.4 \mathrm{~cm}$.

The maximum value of this index reached in the version with fertilization into the soil at a dose of $4 \mathrm{~kg} \mathrm{Mn}$ on ha. On using the lower and higher doses of manganese sulphate, its effectiveness was reducing.
Photosynthetic efficiency criterion is the accumulation intensity of dry biomass by above ground plant organs, the level of which is determined by the synthesis of organic substances and spending them on the process of breathing. The data show that with increasing doses of manganese sulphate to a certain limit $(4 \mathrm{~kg} / \mathrm{ha})$ in phase of sap flow the diameter of shoots amounted to $6.0 \mathrm{~mm}$, in blooming phase $5.7 \mathrm{~mm}$, in growth phase and early fruit ripening $5.2 \mathrm{~mm}$.

Our studies on studying the nature of Platovsky grapes leaf surface development showed that upon depending on the dose and timing of manganese fertilizers, the number of leaves on one bush, area of the leaf blade, as well as the total area of leaves on one bush on 1 ha change. In 2011 there have been favorable conditions for over wintering of grapes during the growing season. On determining the average weight of the fruit mass there has been found that manganese stimulates growth of berries significantly increasing their weight. 
Table 4. Time and dose influence of manganese fertilizer insertion on growth, development and productivity of grapes Platovsky plants (2012).

\begin{tabular}{|c|c|c|c|c|c|c|}
\hline \multirow[b]{2}{*}{ Options of experience } & \multirow{2}{*}{$\begin{array}{l}\text { The average length } \\
\text { of shoots, } \mathrm{cm}\end{array}$} & \multirow{2}{*}{$\begin{array}{l}\text { The average diameter } \\
\text { of shoots, } \mathrm{mm}\end{array}$} & \multirow[t]{2}{*}{ Yield, t/ha } & \multirow{2}{*}{$\begin{array}{l}\text { Sugar content, } \\
\mathrm{g} / \mathrm{dm} 3\end{array}$} & \multicolumn{2}{|c|}{ Increase to control } \\
\hline & & & & & t/ha & $\mathrm{g} / \mathrm{dm}^{3}$ \\
\hline \multicolumn{7}{|c|}{ Insertion into the phase of sap flow } \\
\hline $\begin{array}{l}\text { I. Control (without micronutrients } \\
\mathrm{N}_{90} \mathrm{P}_{90} \mathrm{~K}_{90} \text { background) }\end{array}$ & 133,8 & 5,1 & 19,9 & 181 & - & - \\
\hline II. Background $+\mathrm{Mn}-2 \mathrm{~kg} / \mathrm{ha}$ & 146,9 & 5,4 & 21,9 & 183 & 2,0 & 0,2 \\
\hline III. Background + Mn-4 kg/ha & 167,9 & 5,8 & 24,5 & 190 & 4,6 & 0,9 \\
\hline IV. Background + Mn-6 kg/ha & 150,0 & 5,6 & 23,3 & 186 & 3,4 & 0,5 \\
\hline V. Background + Mn-8 kg/ha & 145,6 & 5,4 & 20,7 & 184 & 0,8 & 0,3 \\
\hline $\mathrm{LSD}_{05}$ & & & 1,863 & & & \\
\hline \multicolumn{7}{|c|}{ Insertion into the flowering phase } \\
\hline $\begin{array}{l}\text { I. Control (without micronutrients } \\
\mathrm{N}_{90} \mathrm{P}_{90} \mathrm{~K}_{90} \text { background) }\end{array}$ & 127,8 & 5,1 & 19,9 & 180 & - & - \\
\hline II. Background + Mn-2 kg/ha & 141,7 & 5,7 & 21,7 & 181 & 1,8 & 0,1 \\
\hline III. Background + Mn-4 kg/haa & 150,0 & 5,7 & 24,8 & 186 & 4,9 & 0,6 \\
\hline IV. Background + Mn-6 kg/ha & 142,8 & 5,6 & 23,9 & 183 & 4,0 & 0,3 \\
\hline V. Background + Mn-8 kg/ha & 134,9 & 5,6 & 20,9 & 182 & 1,0 & 0,2 \\
\hline $\mathrm{LSD}_{05}$ & & & 1,603 & & & \\
\hline \multicolumn{7}{|c|}{ Insertion into the phase of growth and beginning of berries ripening } \\
\hline $\begin{array}{l}\text { I. Control (without micronutrients } \\
\mathrm{N}_{90} \mathrm{P}_{90} \mathrm{~K}_{90} \text { background) }\end{array}$ & 125,8 & 5,1 & 19,9 & 181 & - & \\
\hline II. Background + Mn-2 kg/ha & 129,9 & 5,2 & 21,6 & 182 & 1,7 & 0,1 \\
\hline III. Background + Mn- $4 \mathrm{~kg} / \mathrm{ha}$ & 145,9 & 5,5 & 22,6 & 186 & 2,7 & 0,5 \\
\hline IV. Background + Mn-6 kg/ha & 130,0 & 5,2 & 21,1 & 185 & 1,2 & 0,4 \\
\hline V. Background + Mn-8 kg/ha & 127,0 & 5,2 & 20,0 & 184 & 0,1 & 0,3 \\
\hline $\mathrm{LSD}_{05}$ & & & 2,244 & & & \\
\hline
\end{tabular}

Comparing the option, the background $\mathrm{N}_{90} \mathrm{P}_{90} \mathrm{~K}_{90}$ where only macro fertilizers were inserted and Platovsky grade yield was 69.9 t/ha with the option background $\mathrm{N}_{90} \mathrm{P}_{90} \mathrm{~K}_{90}+$ manganese $2 \mathrm{~kg}$ of active ingredient, yield is higher than $71.6 \mathrm{~kg} / \mathrm{ha}$, the increase was $1.7 \mathrm{t} / \mathrm{ha}$. On $\mathrm{LSD}_{05}=1.553$ the differences on experience options of yield are significant. Sugar content of berries also increased by $2 \mathrm{~g} / \mathrm{dm}^{3}$.

The highest rates in development and productivity of plants are obtained by manganese insertion into the phase of sap flow in the amount of $4 \mathrm{~kg} / \mathrm{ha}$, where the yield was $74.6 \mathrm{t} / \mathrm{ha}$ or above $3 \mathrm{~kg} / \mathrm{ha}$, compared to the dose of manganese $2 \mathrm{~kg} / \mathrm{ha}$. On $\mathrm{LSD}_{05}=1.553$ the differences on experience options of yield are significant.

As it is seen in Table 3, more intense recovery of Platovsky grade root system after a harsh winter in 2012 on manganese insertion into the phase of sap flow occurred at a dose of $4 \mathrm{~kg} / \mathrm{ha}$. Number of skeletal roots in option 3 is more to $40 \mathrm{pcs}$ than in the second option, on manganese insertion at $2 \mathrm{~kg} / \mathrm{ha}$. As it has been noted above, the formation and growth of the root system are interconnected with the life of the aerial plant organs.

The more actively root system develops, and the higher its absorptive capacity is, the more intense the growth of aboveground plant biomass accumulation and the formation of the leaf surface happen.

As our studies showed, manganese fertilizer had a positive effect on plant growth even in 2012 (Table 4).

Thus, on insertion in the phase of sap flow the average length of shoots on the control made without fertilizer was $133,8 \mathrm{~cm}$, in option of manganese insertion in the dose of $4 \mathrm{~kg} / \mathrm{ha}$ in this phase $-167.9 \mathrm{~cm},-150 \mathrm{~cm}$ in flowering phase, in a growth phase and early berries ripening was 145.9 . The most actively growing were plants when making fertilizer into the phase of sap flow.

The maximum value of this index reached in the option with insertion of fertilizers into the soil at a dose of $4 \mathrm{Mn} \mathrm{kg}$ per hectare, while using lower and higher doses of micronutrient its efficiency decreased. The data show that as the sprouting the dose of manganese sulphate to a certain limit (4 kg/ha) in the phase of sap flow, the diameter was $5.8 \mathrm{~mm}$ at the flowering stage $-5.7 \mathrm{~mm}$, in the growth phase and early fruit ripening $-5,5 \mathrm{~mm}$.

On insertion into the soil a higher amount thereof $(6 \mathrm{~kg} / \mathrm{ha}$ and $8 \mathrm{~kg} / \mathrm{ha})$ the growth of shoots and their diameter are increased. A similar effect occurs in the case of $\mathrm{Mn}$ appliance in doses of $2 \mathrm{~kg} / \mathrm{ha}$. Based on these data, we may conclude that for activation the grape production process it is sufficient the insertion of manganese fertilizer in a dose of $4 \mathrm{~kg} / \mathrm{ha}$ (Table 4 ).

\section{Conclusions}

1. Manganese content in the soil profile pilot area varies greatly, ranging from 8 to $24.3 \mathrm{mg}$ or 15 times less than in the alluvial soils of the Chechen Republic.

2. Manganese feeding is effective farming techniques promoting the growth of development, hardiness and productivity of grape plants.

3. The greatest effect of manganese fertilizer insertion is achieved on introducing it into the phase of sap flow at a dose of $4 \mathrm{~kg} / \mathrm{ha}$ on the background of $\mathrm{N}_{90}$, 
$\mathrm{P}_{90}, \mathrm{~K}_{90}$. In order to expedite the recovery of vineyards damaged by frosts to enhance the development of reproductive organs must be introduced on sandy soils $4 \mathrm{~kg} / \mathrm{ha}$ manganese into the phase of sap flow.

\section{References}

[1] GOST (state standard) 27198-87. Vinogradsvet: Methods for determination of the mass concentration of sugars - M. 1987

[2] GOST (state standard)P51621-2000. Alcoholic products and raw materials for its production. Methods for determination of the mass concentration of titratable acids - M. 2000

[3] Zhurbitskiy Z.I. Physiological and agrochemical basis of fertilizer application. M. AS USSR, 1963

[4] Malykh G.P., Magomadov A.S.Viticulture of the Chechen Republic. Monograph/Novocherkassk: Publishing House of RSRI, 2011. - p. 351
[5] Malykh G.P., Magomadov A.S. Modern technologies of reproduction creation and planting of grapes. Monograph -Novocherkassk: Publishing House of RSRI, 2012. - p.149

[6] Sheudzhen A.H., Aleshin N.E. Micronutrients in crop / Ed. By E.N. Aleshin/Allrussian Inst. of Rice. Ministy of agriculture of Adygea republic. 23. Maikop. Rossp. Polygraph. Adygea, 1994

[7] Zakharova E.I., Mashinskaya L.P. Agrotechnical studies on establishment of intensive vineyards on an industrial basis / Novocherkassk. Publishing House of Voroshilovgradskaya truth, 1978. - p.173

[8] Levy, J. F., G. Chaler. Identification et etuda par lanalyse foliaire de quelques carences alimentaires dans le Midi de la France.3 Colloque Europeenet Mediterraneen. Montpellier, 1964

[9] Beyers, E. Diagnostic leaf analysis for deciduous fruit. - South Africa Journal of Agricultural Science, 5, (2), 1962, 315-329 